\title{
TRIBUNAL DE CONTAS - CONTROLE DE SERVIÇO CONCEDIDO
}

\author{
III Seminário de Direito Administrativo Controle das \\ Políticas Públicas Proteção do Usuário \\ Controle pelos Tribunais de Contas da Eficiência e \\ Eficácia dos Serviços Concedidos
}

LUCIANO FERRAZ

O Sr. Luciano Ferraz - Sr. Presidente, tirante os exageros cometidos na minha apresentação, gostaria de agradecer a oportunidade de estar aqui no Tribunal de Contas do Município de São Paulo. Quero saudar os demais Conselheiros que integram essa mesa, o Diretor Administrativo, o Diretor Geral, os servidores desta Corte de Contas e dizer que é a segunda vez que me vejo nesta Mesa, a dos Conselheiros, pois aqui estive no ano de 2000, proferindo exposição sobre a Lei de Responsabilidade Fiscal, nos eventos organizados pela Associação dos Tribunais de Contas do Brasil - ATRICON, juntamente com outros professores, Carlos Pinto Coelho Motta e Jair Eduardo Santana. Naquela oportunidade - logo depois que a LRF saiu -, tivemos oportunidade de explanar algumas idéias sobre a nova legislação. Sinto-me extremamente agradecido pelo convite, e espero corresponder com a exposição que farei sobre o Controle da eficiência e da eficácia dos serviços públicos concedidos no Brasil. Bom, vou começar trabalhando algumas noções genéricas sobre controle, depois adentrarei a questão do controle na Constituição de 1988, especificamente controle externo; após, apontarei o controle externo das licitações e contratos, para então fazer considerações sobre concessão de serviço público, culminando na apresentação da minha perspectiva pessoal, acerca do controle pelos Tribunais de Contas das concessões serviços públicos concedidos no Brasil.

A noção de controle adentra a teoria do Estado a partir da assunção do paradigma do Estado de Direito, que consagra, entre os seus pilares, as idéias de separação de 
funções estatais e do controle do poder político, como formas de garantia das liberdades individuais, direitos de primeira geração. A noção subjacente é a do exercício limitado do Poder. É necessário que o Poder o controle do Poder, como modo de evitar o exercício abusivo, esta é a noção trabalhada por John Locke e Montesquieu. A partir daí, agregam-se historicamente ao Estado de Direito ideários republicanos e democráticos, emergindo noções como: coisa pública e participação popular, patrimônio público e controle social. Aos direitos de primeira geração, paulatinamente, agregam-se novas gerações de direito, que começam a ser consagrados nos Textos Constitucionais do Século XX. Primeiro, os direitos sociais e políticos, os de $2^{a}$ Geração, depois, os direitos coletivos e difusos, os de terceira geração e, mais recentemente, os direitos típicos da democracia participativa, direitos de $4^{\circ}$ geração (Paulo Bonavides). Percebe-se que as Constituições modernas retratam, sobretudo, a partir da Constituição Portuguesa de 1976, quatro gerações de direito, albergando direitos individuais, sociais e políticos, coletivo e difusos, e ainda, direitos genuínos da democracia de participativa. Essa constitucionalização da democracia é, sem dúvida, a tônica do Direito Administrativo Moderno, o Direito Administrativo participativo. De se notar que, de há muito, desde a declaração dos direitos do homem é do cidadão de 1789 , estava previsto que a Sociedade teria direito de pedir contas aos seus agentes públicos. Todavia, somente quando os valores democráticos se alçam ao nível constitucional é que surge nova visão, a da participação da sociedade no exercício da administração ativa e, também, no exercício da administração controladora. No particular, a Constituição Brasileira é benfazeja, pois fomenta a participação da sociedade no controle das funções estatais, seja por intermédio de instrumentos que provocam controles tradicionais, seja por intermédio, mesmo, da participação direta da sociedade, a modo de exemplo, mediante participação nos chamados Conselhos Gestores de Políticas Públicas. Isto acontece no âmbito da saúde, da educação, da criança e do adolescente em diversas áreas sensíveis da atividade estatal. Não é por falta de instrumento de controle que, às vezes, vivemos situação de descontrole. A Constituição prevê controle pela própria administração, o autocontrole, ela prevê a existência de Órgãos de Controle Interno que devem trabalhar conjuntamente com os Órgãos de Controle Externo na avaliação e na fiscalização da atividade financeira, orçamentária, patrimonial e operacional do Estado, prevê controle pelo Ministério Público, por intermédio de ações e de inquéritos civis públicos, para áreas sensíveis como a do patrimônio público, meio ambiente, consumidor. Existe o controle pelo Poder Legislativo. Existe controle pelo Poder Judiciário, que pode ser provocado Ou seja, temos uma gama enorme de instrumentos de controle previstos na Constituição, instrumentos formais, ou seja, instrumentos estatais, e instrumentos que contam com a participação da sociedade. Quero me ater, então, a um signo que a Constituição trabalha. Refiro-me ao chamado Controle Externo da Administração Pública. O Constituinte de 1.988 utilizou o signo Controle Externo com uma significação especial, que nem sempre consta dos manuais que trabalham o tema. Na verdade, a Constituição de 1988 , quando se valeu da expressão controle externo, quis se referir a algo diferente mais especificado, controle externo na Constituição de 88 significa, portanto, a fiscalização financeira, orçamentária, patrimonial e operacional das entidades da federação que se realiza 
por intermédio de dois órgãos, o Poder Legislativo e o Tribunal de Contas. Bem de ver que os órgãos de Controle Interno tem, praticamente, as mesmas competências dos Órgãos de Controle Externo, somente a forma de exteriorização e as consequiências do exercício desse controle é que são diversas, mas em termos de objeto do controle, das matérias sindicadas, são praticamente as mesmas competências deferidas constitucionalmente a ambos esses órgãos. O Controle Externo atua no mesmo âmbito do controle Interno, nas matérias concernentes à fiscalização financeira, orçamentária, patrimonial e operacional da Administração Pública, conforme está descrito, com todas as letras, no artigo 70, da Constituição. Este dispositivo diz que essa fiscalização fica a cargo do Congresso Nacional que a realizará mediante controle externo e pelo sistema de controle interno de cada Poder. Ou seja, controle interno e controle externo controlam os mesmos passos no âmbito da Administração Pública. Muito bem, mas na leitura textual deste dispositivo fica parecendo que a matéria Controle Externo se esgota no âmbito do Pode Legislativo. Definitivamente, essa não me parece seja a determinação dada pelo Constituinte de 1.988. Na verdade. a expressão e a matéria correlata, controle externo, se subdivide em duas espécies: o chamado controle diretamente exercido pelo Tribunal de Contas e o chamado controle parlamentar indireto. Explicito melhor: O Poder Legislativo, na Constituição, tem a seu cargo atividade de legislação e de controle. Muito bem, em determinadas hipóteses, o Poder Legislativo exerce esse controle ele mesmo Poder Legislativo, independentemente, da colaboração de qualquer outro órgão estatal, ou seja, o Poder Legislativo, ele próprio, valendo-se de sua estrutura, exerce a atividade de controle. É o que se dá, por exemplo, nas Comissões Parlamentares de Inquérito, que o Legislativo exerce a competência ele mesmo, é o que se dá no julgamento dos crimes de responsabilidade do Presidente da República e seus correlatos, é o que se dá na convocação de Ministros de Estados para prestar esclarecimentos, no petitório de esclarecimentos escritos, na sustação dos atos normativos que exorbitem do Poder regulamentar ou da delegação legislativa, todas essas hipóteses, vejam bem, são hipóteses de controle, a cargo do parlamento, mas que o parlamento exerce ele mesmo sem qualquer necessidade de colaboração de um outro órgão estatal. Muito bem, só que este âmbito não esgota o âmbito de atividade controladora atribuída ao parlamento; ao lado dessa possibilidade, a do controle parlamentar direto, aquele exercido diretamente pelo Poder legislativo, o Constituinte albergou competências para que o legislativo exerce outras atividades controladoras, mas prescrevendo-lhe o auxílio do Tribunal de Contas. Então, numa determinada seara de movimentos da Administração, o Parlamento não exerce por si só o controle, ele exerce o Controle com a colaboração, com o auxílio do Tribunal de Contas. Note-se que é por isso, que o artigo 71 da Constituição Federal diz o seguinte: o Controle Externo a cargo do Congresso Nacional será realizado com auxílio do Tribunal de Contas para o qual arrola uma série de competências que são do próprio Tribunal, exclusivas dele. Noutras palavras, o controle parlamentar da Administração Pública abrange controle parlamentar direto e o controle parlamentar indireto. O controle parlamentar indireto constitui parcela da atividade que o constituinte intitulou controle externo. Em síntese, o que se quer significar com o signo controle externo é um gênero que abarca o controle parlamentar indireto e o controle diretamente exercido pelo Tribunal. Pois 
bem. Como podemos identificar, um e outra, espécie de controle externo. Cite-se como exemplo a prestação de contas anual do Chefe do Poder Executivo. O Executivo presta contas ao Tribunal de Contas que emite um parecer prévio e submete a julgamento do Legislativo. Vejam bem, o julgamento, o ato final da atividade controladora é de competência do legislativo. Contundo, necessariamente o legislativo aí deverá contar com o auxílio do Tribunal, não pode, por exemplo, o Chefe do Executivo prestar contas diretamente ao legislativo, furtando-se da emissão do parecer prévio do Tribunal, isso não pode acontecer; necessariamente o Tribunal deve emitir um parecer, que será depois submetido ao julgamento do Poder Legislativo. Vale dizer, o controle do parlamento é subsidiado por uma análise técnica proferida pelo próprio Tribunal de Contas. Portanto, o julgamento das contas anuis é de controle parlamentar indireto, porque antes de realiza-lo contou o legislativo com o auxílio do Tribunal de Contas.

O mesmo se dá, por exemplo, com as chamada inspeções e auditorias que ficam a cargo do Tribunal de Contas, na forma do artigo 71, inciso IV da Constituição Federal, diz lá: "compete ao Tribunal de Contas realizar por iniciativa própria. ou mediante requisição de qualquer das casas do Congresso Nacional, de Comissão sua, ou de Comissão Parlamentar de Inquérito, inspeções e auditorias de natureza contábil e financeira, orçamentária, operacional e patrimonial em qualquer das atividades administrativas dos três poderes". Vale dizer, que o exercício das inspeções e auditorias com esta natureza pode ser provocada pelo Poder Legislativo. O Poder Legislativo tem a incumbência de provocar o controle do Tribunal, e o Tribunal realiza inspeções e auditorias. O Poder Legislativo, diretamente, não pode realizar inspeções e auditorias dessa natureza, se quiser fazê-lo deve provocar o Tribunal para que ele o faça, ou seja, é uma forma de controle parlamentar indireto.

O mesmo acontece, por exemplo, na hipótese de despesas que podem ser realizadas pelo Poder Executivo ferindo a economia pública, conforme disposição do artigo 72, da Constituição Federal. Esta competência, inclusive, é até um pouco deixada de lado nos estudos sobre o Tribunal de Contas, mas o artigo 72 dá competência ao Tribunal para, se provocado pelo Poder Legislativo, emitir um parecer sobre a despesa, competindo ao parlamento tomar a iniciativa de susta-lá-, se entender necessário. Trata-se, pois, de outra hipótese do controle parlamentar indireto. Eu vou saltar apenas uma que diz respeito ao controle de contratos, porque esta eu voltarei mais na frente.

Vejam bem, arrolei três hipóteses do controle parlamentar indireto, uma deixarei para depois, a do art. $71, \S 1^{\circ}$ da Constituição. Ao lado dessas competências, o Tribunal de Contas exerce uma série de outras competências, sem qualquer interferência do Poder Legislativo. Por exemplo, diz o artigo 71, inciso II competir ao Tribunal de Contas julgar as contas dos administradores e demais responsáveis por bens, dinheiros e valores públicos de todas as esferas. Ou seja, o julgamento de contas é feito pelo Tribunal de Contas, ele julga diretamente, a competência é dele e ninguém tira, competência que nasce do próprio texto constitucional.

Artigo 71, inciso III diz competir ao Tribunal de Contas apreciar para fins de registro, os atos de aposentadoria, reforma e pensão e a admissão de pessoal, veja, o Tribunal registra ele mesmo, ele não submete, posteriormente, ao Poder Legisla- 
tivo, porque essa competência de Controle Externo é deferida pelo Constituinte a ele, Tribunal de Contas.

O mesmo se dá nas auditorias, em inspeções quando são realizadas por iniciativa do próprio Tribunal, também está na Constituição, no artigo 71, inciso IV.

Em síntese, o Controle Externo é um gênero que abarca, duas espécies: Controle Parlamentar Indireto, que é realizado pelo Parlamento com auxílio do Tribunal e Controle diretamente exercido pelo Tribunal de Contas, que este exerce, ele mesmo, sem qualquer interferência do Poder Legislativo ou de qualquer outro órgão estatal.

Bom, feitas essas considerações, devo então, me reportar ao controle que o Tribunal de Contas realiza sobre as Licitações e Contratos Administrativos.

Isto porque, se formos analisar três dispositivos na Constituição: o disposto no artigo 71 , IX, o disposto no artigo $\mathrm{X}$ e o disposto no artigo 71 parágrafo $1^{\circ}$ do texto, vamos chegar a conclusão de que, o Tribunal de Contas, por óbvio, exerce Controle sobre Licitações e Contratos, seja porque são procedimentos típicos da Administração, e mais ainda, porque envolve a repercussão financeira para os cofres do estado.

Por isso o Tribunal de Contas fiscaliza tais atos, ou procedimentos, ou Contratos.

Muito bem, o artigo 71, IX, diz que o Tribunal de Contas, quando realizar a sua atividade de fiscalização, se apurar irregularidade, assinará prazo para que o Órgão ou Entidade adote as providências necessárias para o exato cumprimento da Lei.

Então, o Tribunal de Contas, pode, em se tratando de um procedimento administrativo, em se tratando de um ato administrativo, exercer competência fiscalizatória e assinar prazo para o exato cumprimento da Lei.

Muito bom.

Daí, nós chegarmos à conclusão de que o Tribunal de Contas pode, e a legislação infra-constituicional assim o disciplina, fazer controle de procedimentos administrativos, notadamente do procedimento de Licitação. E se ao longo do procedimento de Licitação o Tribunal de Contas visualiza algum tipo de irregularidade, ele pode assinar prazo para que o órgão ou entidade adote as providências para se adequar ao ordenamento jurídico. Bom, se o Tribunal de Contas assina esse prazo e não é atendido, diz o artigo $71, \mathrm{X}$ tem ele a competência para sustar o ato impugnado. Sustar a eficácia do ato impugnado. Sustar os efeitos do ato impugnado, sob pena de responsabilidade da autoridade.

Note-se que o Constituinte usou a expressão correta, "sustação" do ato. O Tribunal, quando emite esse juízo não se imiscui na questão da validade do ato, porque quem trabalha no âmbito da validade, ou seja, quem pode declarar invalidade do ato, ou é a própria administração ou é o Poder Judiciário.

O Tribunal de Contas, simplesmente emite um ato, que susta os efeitos do procedimento de Licitação.

De outra parte, quando a formalização do Contrato já está realizada, isto é, quando o Contrato já está assinado entre as partes, entre a Administração e o particular, por exemplo, determina o parágrafo $1^{\circ}$ do artigo 71 que a sustação deste Contrato não competirá em princípio ao Tribunal de Contas. A competência para sustação de Contrato, é do Poder Legislativo. 
Ou seja, o Tribunal de Contas provoca o Poder Legislativo, e o Poder Legislativo adota o ato de sustação.

Se o Poder Legislativo ficar inerte pelo prazo de 90 dias, aí a competência vai retornar ao Tribunal de Contas, que poderá então, ele mesmo, sustar os efeitos do Contrato.

Então, vejam bem, em se tratando de Contrato já formalizado, $o$ ato de sustação encerrará uma hipótese de controle parlamentar indireto, pois o Tribunal provocará o Legislativo que adotará o ato de sustação ou não, conforme deliberação dele.

Logo, durante o curso da Licitação, até o momento da adjudicação e mesmo depois dela, antes de haver efetivamente a contratação, a competência de sustação do procedimento, é do Tribunal de Contas.

Depois de formalizado o Contrato, a competência de sustação é do Poder Legislativo, salvo se o Legislativo ficar inerte, uma vez provocado pelo Tribunal, pelo prazo de 90 dias, hipótese em que, a competência para sustação, retornará ao próprio Tribunal de Contas.

Isto está disposto no parágrafo $2^{\circ}$, do artigo 71 . Parágrafo $1^{\circ}$, é sustação pelo Legislativo; parágrafo $2^{\circ}$, o retorno da competência, para que o Tribunal de Contas então, adote evidências a respeito.

Bom, fiz essas breves considerações sobre Licitação e Contrato, porque, na verdade, o Controle deles não será exercido só pelo Tribunal, mas também pelo Poder Legislativo, para adentrar propriamente ao tema das Concessões.

Todo mundo sabe da natureza contratual da concessão de Serviço Público, bem como da permissão de Serviço Público, ainda que haja alguma divergência doutrinária, em se tratando da permissão. Tanto concessão como permissão são contratos administrativos, mediante os quais a Administração realiza a chamada descentralização por colaboração, ou descentralização por delegação.

Ou seja, o serviço continua sendo pertencente ao Poder Público, todavia, a sua execução é repassada a particulares, que são os concessionários ou permissionários de Serviço Público.

E aí então, eu preciso fazer uma incursão, na seara da Constituição, para assumir posição, no que diz respeito aos Serviços Públicos.

Bom, o Constituinte, quando trabalhou a questão do estado, na Constituição de 1988, no âmbito da Ordem Econômica, disse que, o Poder Público, não intervirá no âmbito da exploração de atividades econômicas, salvo quando haja relevante interesse coletivo ou nos casos de segurança nacional; vale dizer, que no que diz respeito à exploração de atividades econômicas, o Constituinte estabeleceu para o Estado uma posição subsidiária em relação à iniciativa privada. m outras palavras, o domínio das atividades econômicas, é típico da iniciativa privada.

Diferente é a posição da Carta relativamente aos serviços públicos, porque o artigo 175, da Constituição Federal diz incumbir ao Poder Público, diretamente ou por intermédio de concessãd ou permissão, sempre através de licitação, a prestação de serviços Públicos, na forma da Lei.

Vale dizer que, em se tratando de Serviços Públicos, a competência para prestação é atribuída de maneira genuína ao próprio Estado, todavia, autoriza-se ao 
Estado, a possibilidade de delegação da execução da atividade, para a iniciativa privada.

Muitas vezes, é mesmo recomendável, que assim proceda o Estado, quer dizer, repassando o âmbito dessas atividades, para a iniciativa privada.

Em outras palavras e fazendo um resumo do que eu disse até agora, com relação a esses dois dispositivos (art. 173 e art. 175); Exploração de atividade econômica, domínio típico da iniciativa privada. Serviços públicos, domínio típico do Estado.

Vejam bem, o Brasil adota economia de mercado. Livre concorrência, é Estado capitalista. Tanto a atividade de exploração de atividade econômica, a do artigo 173 , como a exploração de um serviço Público, quando esse serviço é passado pelo particular, visam ao lucro. São, portanto, atividades econômicas.

O particular não entra numa concessão de serviço público para fazer graça para ninguém. Ele entra com o objetivo de obter lucro. Ou seja, a Constituição de 1988 , adota dois conceitos de atividades econômicas: Um conceito de atividade econômica em sentido amplo, que abarcaria, não só a exploração de atividade econômica em sentido estrito, a exploração típica de atividade econômica, como também a prestação de serviços públicos, quando esses serviços são colocados a cargo de particulares, ou seja, quando particulares exploram o serviço público, estamos no âmbito de uma atividade econômica em sentido amplo, porque ele busca lucro, todavia, não se trata de atvidade econômica em sentido estrito, porque está envolvido ali, quem, está envolvido ali o Estado que é o titular do serviço público, por força da própria Constituição.

Em síntese, há um conceito amplo de atividade econômica, que é o conceito que abarca serviços públicos e exploração de atividade econômica em sentido estrito.

E o artigo 174, da Constituição Federal, disciplina também, uma atividade que fica a cargo do Estado como agente normativo e regulador da atividade econômica, e aqui atividade econômica, em sentido amplo, o Estado deverá exercer, na forma da lei, as funções de fiscalização, incentivo e planejamento, sendo este o planejamento determinante para o setor público e indicativo para o setor privado. Ou seja, o Estado tem ainda, a incumbência de funcionar na condição de agente normativo e regulador da atividade econômica.

Chamo a atenção para o atual desenho do Estado brasileiro. O estado brasileiro, quando entra no processo de reforma, e essa reforma se dá, a partir de 1995 com uma série de Emendas Constitucionais, que começam a quebrar os monopólios estatais, seja na área de navegação de cabotagem, seja na área de exploração de atividades petrolíferas, seja na área de telecomunicações, quem se afigurava os monopólios estatais, por força da Constituição de 88 , ele começa a reduzir o seu tamanho, e buscar na iniciativa privada, as pessoas que vão exercer aquelas atividades. Só que quando ele faz isso, ele flexibiliza o controle que ele, Estado, detinha sobre entidades da Administração Indireta, entidades estas que começam a ser privatizadas. E quando ele flexibiliza esse controle, precisa criar novas formas para funcionar na qualidade de agente normativo e regulador da atividade econômica em sentido amplo.

E, nesse passo, é que se encerra a idéia das agências reguladoras. 
E vejam bem, as agências reguladoras, são voltadas para qualquer tipo de atividade econômica, tanto para exploração de atividades econômicas, como a ANVISA, que mexe com produtos farmacêuticos e etc., quanto a ANATEL, que trabalha com serviços públicos concedidos, e esta é a característica, vejam bem, a concessão será, ou é, um instrumento que se amolda ao novo modelo de Estado, o do Estado regulador.

Em suma, o Estado sai da prestação direta de serviços públicos, transferindo-os mediante concessão ou permissão à iniciativa privada, e por conta da perda do controle que ele teve, quando fez esses contratos, porque as entidades não pertencem à Administração Indireta, ele necessita criar novos mecanismos de controle de regulação e de normatividade. É aí que entra o papel das agências reguladoras, que têm justamente a incumbência de funcionar nessa qualidade, exercendo o chamado poder normativo e regulando os setores a que se destinam, ANATEL. telecomunicações; ANEEL, energia elétrica, veja bem, só serviço público.

Quer dizer, a seara dos serviços Públicos é repassada mediante concessão ou permissão, mas a agência reguladora, conserva o papel que lhe é reservado pelo artigo 174, da Constituição Federal.

Bom, feitas essas colocações. então posso trabalhar as concessões. Isto porque, o papel das agências reguladoras, é um papel de normatividade e regulação, e quando eu trabalho com expressão regulação está implícita a atividade de fiscalização. A atividade de controle da execução do objeto das concessões, ou seja, dos contratos das concessões é papel das agências. Vermos adiante a necessidade de estabelecer limites para o exercício das atividades de controle que o Tribunal de Contas pode exercer sobre as concessões, porque ele não substitui o papel das agências reguladoras. É necessário respeitar cada papel.

Bom, a Lei 8987, é a Lei Nacional de Concessões de serviços Públicos.

Aliás, são duas, é a Lei 8987 e a Lei 9074/95. disciplinam normas gerais sobre o assunto. Compete à União, nos termos do artigo 22 inciso XXVII da Constituição, legislar sobre Normas Gerais normas gerais sobre Licitação e Contratos em todas as modalidades, incluídas Concessões e Permissões de Serviços Públicos.

Logo, as Leis 8987 e 9074, constituem-se nas normas gerais de Concessões e Permissões dos Serviços Públicos e Estados e Municípios estão submetidos a estas normas. O que não significa que eles estejam impedidos de também legislarem sobre o assunto,todavia, de maneira apenas suplementar à Legislação Federal, que neste caso é de âmbito Nacional.

Diz aqui o artigo $1^{\circ}$, da Lei de Concessões: "As Concessões de Serviços Públicos e de Obras Públicas e as permissões de Serviços Públicos, reger-se-ão pelos termos do artigo 175, da Constituição Federal, por esta Lei, pelas normas legais pertinentes e pelas cláusulas indispensáveis dos Contratos.

Parágrafo único: A União, os Estados, o Distrito Federal e os Municípios, promoverão a revisão e adaptação necessária de sua legislação às prescrições desta Lei, buscando atender as peculiaridades das diversas modalidades dos seus serviços Públicos:

Artigo $2^{\circ}$ : Para fins do disposto nesta Lei, considera-se, poder concedente, a União, o Estado, o Distrito Federal, o Município, em cuja competência se encontra 
o Serviço Público precedido ou não, da execução de obra, objeto de Concessão ou Permissão".

Muito bem. é da essência, portanto, do Contrato de Concessão, a existência de uma relação trilateral, uma relação que se estabelece entre o Poder Concedente, que é o titular do serviço Público, o concessionário ou permissionário, que recebe a delegação para a execução do Serviço Público, e o usuário do Serviço, que é aquele que receberá a prestação do serviço.

A Concessão clássica, o tipo de Concessão clássica, estabelece que a remunerabilidade do Concessionário advém das tarifas que ele cobra diretamente dos usuários dos Serviços Públicos, ou seja, cobrando as tarifas do usuário, o particular se remunera pelo fato de prestar o serviço em prol da sociedade, por delegação do Poder Público.

E o Poder Público tem a incumbência, na qualidade do poder concedente, de fiscalizar a execução daquele contrato, para saber se o concessionário está dando cumprimento ao que está estabelecido na Constituição, na Lei de Concessões, nos normativos das agências reguladoras e nas cláusulas estabelecidas no próprio Contrato de Concessão.

Por que controlar a Concessão?

Vamos controlar a Concessão por uma série de fatores.

Primeiro: trata-se de contrato administrativo, de modo que envolve interesse da Administração Pública.

Segundo: trata-se de contrato administrativo que envolve serviço público. Quer dizer, serviço que é prestado diretamente à sociedade. Serviço, cuja titularidade é do Poder Público, e quando ele repassa a execução dele para a iniciativa Privada, não deixa de ser do Poder Pública a incumbência de fiscalizar a prestação.

Bom, afinal, como se deve controlar as Concessões. Como os Tribunais de Contas poderão controlar a concessão?

Controlar o processo de outorga da Concessão, ou seja, a Licitação de Concessão é uma coisa. Controlar a execução do Contrato de Concessão é outra coisa.

Vale dizer, que o Tribunal de Contas pode exercer controle sobre o processo de outorga da Concessão, porquanto ele será feito, por força do artigo 175 da Constituição, sempre através de Licitação e o Tribunal de Contas tem competência para fiscalizar licitações.

Então, é necessário que o Tribunal de Contas acompanhe desde o início, este processo de Licitação, das Concessões, tendo em vista os princípios que a Administração Pública deve respeito.

O artigo $6^{\circ}$, por exemplo, da Lei de Concessões, diz que, toda Concessão ou Permissão, pressupõe Prestação de Serviço adequado, ao pleno atendimento aos usuários, conforme estabelecido nesta Lei, nas normas pertinentes e no respectivo Contrato.

Serviço adequado é o que satisfaz as condições de regularidade, continuidade, eficiência, segurança, atualidade, generalidade, cortesia na sua prestação e modicidade das tarifas, ou seja, o serviço quando é concedido, o é por intermédio de um processo de Licitação, que deve respeito a toda normatividade aplicável, e o Tribunal de Contas deverá acompanhar de perto este processo de Licitação. 
Obviamente, que o Controle que o Tribunal de Contas exercerá será direcionado às normas e aos princípios que regem o procedimento de Licitação, competitividade, julgamento objetivo, vinculação ao edital, isonomia, garantia da proposta mais vantajosa e daí por diante.

Nesse passo, chamo a atenção para um dispositivo da Lei de Concessões, extremamente importante, em se tratando de serviço público. Refiro-me ao artigo $5^{\circ}$, da Lei 8987 , da Lei de Concessões, que diz o seguinte: O Poder concedente. publicará previamente ao edital de licitação, ato justificando a conveniência da outorga de concessão, ou permissão. caracterizando seu objeto, área e prazo.

Vejam bem: o Legislador da Lei de Concessões exigiu do Poder Concedente, para que proceda à outorga, um ato motivador dessa outorga, pelo qual deve ficar claro, por exemplo, a conveniência da outorga da Concessão. Ora, conveniência da outorga da Concessão ou Permissão, caracterizando o objeto, área e prazo.

Será que toda e qualquer hipótese, é conveniente e oportuna à outorga de concessão ou permissão? Em outras palavras, o que fez o artigo $5^{\circ}$, senão retirar da Administração Pública, do Poder concedente, a possibilidade de maneira discricionariamente e sem qualquer justificativa prévia, outorgar serviços públicos? Pode ser que no momento em que há a outorga desse serviço público, a Administração não atenda o princípio de eficiência, não atenda ao princípio da economicidade; não atenda ao serviço adequado; não atenda à modicidade das tarifas.

Aliás, no meu modo de entender, o princípio da modicidade é a chave para universalização dos serviços públicos, pois quanto mais módica for a tarifa a ser cobrada, maior será a possibilidade de utilização do serviço, por parte da sociedade, por parte do usuário. Então a modicidade da tarifa é a questão chave no âmbito da concessão.

Logo, mediante o ato justificador, sobreleva-se a chamada teoria dos motivos determinantes, pelo qual a administração se vincula aos motivos que alega, no momento de uma prática de ato Administrativo. Dessa forma, a justificativa do artigo $5^{\circ}$, para outorga da concessão, vinculará a Administração Pública, de sorte que se os motivos alegados forem inexistentes ou forem inverídicos, isto levará necessariamente à nulidade da outorga da concessão.

Ressalto, portanto, a relevância do artigo $5^{\circ}$ da Lei de Concessões, sobretudo no controle que o Tribunal de Contas poderá realizar, antes mesmo, do procedimento de licitação, porque o Tribunal de Contas poderá fiscalizar os motivos que são alegados, para saber se eles efetivamente levam a uma melhor alternativa, ou pelo menos a uma razoável alternativa, em se tratando de Concessão ou Permissão.

Outra é a questão relativa ao controle da execução do Contrato. Tem o Tribunal de Contas competência para fiscalizar a execução do contrato. Todavia, se quiser adotar atos de sustação do Contrato, não poderá fazê-lo porque esta competência fica a cargo do Parlamento. e dos respectivos correlatos em estados ou municípios. quer diz

Contudo, eis as grandes perguntas que se colocam:

Como se deve controlar a execução desses Contratos de Concessão?

Como o Tribunal de Contas deve fazê-lo, para provocar o controle a cargo do Legislativo? 
Nesse particular, chamo a atenção para uma nova visão que se deve ter sobre o Controle da Administração Pública.

Somos um país, que adotou um modelo de Administração calcado, sobretudo, no aspecto normativo. Por isso, a maioria dos autores diz que Administrar é executar a lei de ofício, é dar cumprimento a regras pré-estabelecidas pelo Legislador.

$\mathrm{Na}$ verdade, esta visão corresponde a um Estado que não mais existe. O Estado Liberal. Nele a atuação do Estado era tão diminuta, que efetivamente, a sua atuação era simplesmente executar conteúdo pré-estabelecido de Lei. Mas, as alterações que o Estado ao longo do tempo sofre, seja na assunção do Estado social, seja na assunção do Estado regulador, que atualmente caminhamos para ele, mudam essa perspectiva.

Hoje, o Estado chama para si, sobretudo do ponto de vista da Administração Pública, tantas atribuições, que é meramente impossível, humanamente impossível, querer reconduzir todas essas atividades, ao que pré-estabeleceu o Legislador. $\mathrm{O}$ Administrador não pode ser mero robô na aplicação de conceitos, que foram definidos anteriormente pelo Legislador. Na verdade, o ato de Administração, é um ato de criação do próprio direito, e a perspectiva que está a vincular a atividade do administrador hoje, não é mais uma perspectiva, somente de legalidade, é uma perspectiva que envolve outras dimensões, valores que se positivam por intermédio de princípios no âmbito da Constituição Brasileira de 1988. É a tendência pós-positivista do Direito, que visualiza o Direito, não como conjunto de regras, o artigo tal, da Lei tal, mas como um conjunto de princípios e regras. Quer dizer, um conjunto de normas, com eficácia dever-ser jurídico. Normas que buscam regular a atividade da Administração.

E o princípio da legalidade, portanto, é apenas um, e não o tal, o tal e qual, que regula a Administração Pública. Os outros princípios regulam da mesma forma a atuação da Administração Pública: moralidade, publicidade, economicidade, eficiência, e daí por diante.

Eu realizo esse estudo isso num trabalho tentando demonstrar essa nova dimensão do Direito utilizando-me de uma metáfora, que é a metáfora do arco-íris. Eu o chamo arco-íris normativo. É porque, hoje, a incidência do direito sobre os atos da administração é uma incidência que se faz à moda de um arco-íris; existem várias faixas de normatividade incidindo sobre a atuação do administrador. A faixa da legalidade é apenas a mais nítida, a mais visível, aquela que se consegue enxergar a olho nu. Às vezes, não se consegue saber quando termina e quando acaba uma e outra faixa, havendo mesmo áreas de penumbra entre uma e outra e que, não raro é necessário que o administrador, no momento de praticar o ato, faça um juízo de ponderação entre um ou outro princípio para saber qual que deve prevalecer ou ceder espaço no caso concreto. Ou seja, nem sempre dar cumprimento, à risca, ao que a legalidade dispõe, serve mais ao direito do que simplesmente ignorá-la para abarcar, para prestigiar outro princípio, outro vetor da administração pública.

Chamo a atenção para a revolução que esse modo de perceber o Direito traz para a atividade de controle da Administração Pública. Sob a perspectiva de uma administração que é meramente executora da lei, que é uma administração pautada, exclusivamente, pela rigidez do princípio da legalidade, o controle da administração pública tem determinadas características. Primeiro, ele vai se voltar ao ato adminis- 
trativo isoladamente considerado. Vai se voltar para o ato, quer dizer, vai ser um controle pontual porque se a atividade de administração é simplesmente buscar o conteúdo da norma e concretizar, o que interessa é ver se a concretização está de acordo ou não está de acordo com a lei aplicável ao caso concreto. Segundo, o controle é sempre um controle de correção, ou seja, um controle com características tipicamente corretivas e sancionatórias. Isto porque quando se aplica a lei ao caso concreto e verifica-se se o ato é conforme ou desconforme, caso seja ele desconforme à lei, necessariamente, caberá tomar providências para a correção daquele ato e para aplicar sanção ao seu responsável. Ou seja, o controle assume assim uma característica pontual e repressiva.

Outro é a possibilidade de controle numa perspectiva ampliada do Direito, a que envolve a questão principiológica, o controle não pode ser, exclusivamente, voltado para o ato administrativo. Tem que ser um controle que se volta para a gestão pública. Tem que ser um controle que se volta para um conjunto de medidas adotadas pela administração para implementar políticas públicas consistentes e efetivas. Assim o controle deixa de ser pontual para ser um controle global e deixa de ser repressivo para se tornar nitidamente propulsivo: um controle que busca não detectar falta e aplicar a sanção, mas que detecta a falta para propor soluções.

Anoto que Henry Fayol, desde o início do século XX, sustentava que a função da atividade de controle seria a de detectar as faltas e propor soluções. No controle tradicional, todas as vezes que o administrador pratica um ato que esteja desconforme a uma regra legal, violou um artigo tal, da lei tal está errado e deve ser sancionado.

Não me parece seja esta a tônica que deve ter o juízo de controle externo. $O$ Tribunal de Contas tem possibilidades muito mais fortes no exercício do controle. Porque é ele juntamente com os órgãos de controle interno quem controla gestão pública no Brasil. O poder judiciário não controla gestão, só controla ato e o controle sobre o ato não permite separar o joio do trigo, pois é nitidamente controle de correção.

A Ciência da Administração (privada) avança no estudo da gestão pública. Marc Zegan, um dos teóricos que se debruçam sobre o tema, diz que na administração privada não interessa se o sujeito acerta dez por cento do seu tempo e erra noventa, porque o que interessa é se ele gerou lucro ao final do exercício. Já na Administração Pública, diz o mesmo Marc Zegan, não interessa que ele acerte noventa e nove por cento do seu tempo porque os olhos estarão voltados para o um por cento que ele esteve errado. Errar é humano. É necessário que se faça a separação do joio e do trigo e eu não consigo fazer essa separação se o controle que exerço é voltado exclusivamente, para o ato administrativo. Quando fiscalizo o ato, fiscalizo aquela conduta especificada e não a globalidade das condutas adotadas pelo administrador. Assim, não separo o joio do trigo. Bem por isso as auditorias de gestão são o grande passo a ser implementado pelos Tribunais de Contas no Brasil. Ele tem competência para tanto disposta no artigo 71 , IV da Constituição. Então, ao invés de uma visão voltada para as auditorias de regularidade, focada no binômio "se" e "então", de sorte que se um ato foi praticado diferente do que dispõe a lei, então deve ser a sanção, que é o modelo kelseniano de Direito e o modelo weberiano de administração, melhor trabalhar com objetivos e metas, que é o modelo de Peter Druker, o da 
administração por objetivos, e ao mesmo tempo trabalhar com o Direito na perspectiva dos princípios, sobretudo do princípio da eficiência. É por isso que na minha modesta visão o foco do controle deve ser a gestão e a juridicidade e não o ato administrativo e a legalidade em sentido estrito.

Adentro, portanto, a questão do princípio da eficiência e depois concluirei fazendo a sua ligação com a questão das concessões de serviços públicos. Muito bem, o princípio da eficiência na Constituição de 1988, dizem alguns autores, é sinônimo de boa administração, não precisava estar no Texto Constitucional. Na verdade, a eficiência sempre esteve na Constituição de 1988.0 artigo 74 , inciso II, determina que legislativo, executivo e judiciário, mantenham de forma integrada sistemas de controle interno com a finalidade de comprovar a legalidade e avaliar os resultados quanto à eficácia e a eficiência da gestão orçamentária, financeira e patrimonial nos órgãos da administração. Isso é do texto originário. Então não foi com a Emenda 19 que a eficiência entrou na Constituição. Já estava lá. Mas a inclusão do artigo 37 do princípio da eficiência tem um efeito irradiador muito importante, não porque traz novos ventos, ventos neoliberais, mas para deixar patenteado que há, ao lado dos demais princípios, um dever-ser de eficiência. Porque o princípio é dever-ser. Um dever-ser de eficiência. Contudo, particularmente faço uma leitura diferenciada da inclusão do princípio da eficiência no artigo 37 da Constituição. Entendo que o constituinte no artigo 74, II, utilizou a eficiência com uma significação unidimencional, ao passo que no artigo 37 utilizou eficiência com uma visão maior. É como se o artigo 37, "caput", fosse eficiência no sentido amplo e o artigo 74, inciso II fosse eficiência em sentido estrito. Vou tentar mostrar o que me parece seja cada uma destas eficiências. A eficiência que está disposta no artigo 74 , inciso II ao lado da eficácia, é uma eficiência unidimencional no sentido de corresponder à relação que se tem entre produtos gerados, vale dizer, bens e serviços, e o custo dos insumos empregados. Quer dizer, maximização dos meios. Então, eficiência no artigo 74 , II não se liga à idéia de resultado, não se liga à idéia de atingimento de metas. Lá, a eficiência é tratada no sentido de maximização dos meios. Quer dizer, eu consigo ser eficiente se com os meios colocados à minha disposição consigo otimizar o resultado da ação. Ou seja, se consigo otimizar os meios para o alcance dos resultados. Esse é o conceito que me vem à cabeça de eficiência em sentido estrito, que estaria está conectada com a eficácia. A eficácia, por sua vez, diz respeito ao atingimento de metas preestabelecidas. Atingir resultados, na verdade, não é ser eficiente, é ser eficaz, é cumprir metas preestabelecidas. Então, eficácia diz respeito a atingimento de resultados esperados. Eficiência diz respeito a atingimento de resultados maximizando, otimizando bens e produtos postos à disposição. Quer dizer, maximizando os meios. Por fim, cabe mencionar economicidade, que é a minimização dos custos da atividade sem perdas nos padrões de qualidade.

Vejam bem que é interessante. $\mathrm{O}$ artigo que trata dos Tribunais de Contas, do controle externo da administração tem a economicidade no artigo 70 , a eficácia e a eficiência no artigo 74, II. E mais, tem a legitimidade no artigo 70 , porque legitimidade é sinônimo de juridicidade, controle amplo, controle ampliado, que abarca economicidade, que abarca eficiência em sentido estrito, que abarca eficácia. Repito, economicidade - diminuição de custo sem perda de qualidade; eficiência - ma- 
ximização dos meios para alcance do resultado; eficácia - alcance do resultado. Então, vejam bem que aí há os $3 S$ das técnicas de auditoria: economicidade, eficiência e eficácia. Daí que o artigo 37, "caput" quando traz o princípio da eficiência, o traz numa perspectiva diferente, numa perspectiva ampliada, que na verdade reúne economicidade, eficácia e eficiência. O que quer o constituinte é que a Administração Pública seja econômica, que ela atinja os resultados e que utilize os meios maximizadamente, que dizer, de maneira qualitativa no emprego dos meios postos à disposição. Então, a eficiência no artigo 37 está a abarcar todas essas idéias, mas está a abarcar, ainda, outra idéia. A idéia de efetividade. E a idéia de efetividade, que tem de ver com o âmbito da chamada maximização dos efeitos sociais da ação de governo, da atividade de administração. Quer dizer que a efetividade, primeiro, se relaciona à prática de políticas públicas, se determinada política pública resultou em benefícios à sociedade. Isso é ser efetivo, é maximizar resultados sociais. Dou exemplo para ficar claro. O Município começa um programa de desenvolvimento para alfabetização de adultos. Eu digo no início do programa: vou alfabetizar 500 alunos por ano. Vou utilizar, para tanto. dos meus próprios meios. Vou deslocar professores que estão ociosos em dados órgãos, vou deslocar para essa atividade. E isso me custará tanto por mês, quinhentos mil reais por ano. Muito bem, se ao final do prazo de um ano, eu vou avaliar aquele programa, e vou dizer, realmente treinei 500 adultos, portanto, eu fui eficaz. Eu utilizei dos meios que estavam a minha disposição sem gerar ônus e não perdeu qualidade nenhuma, eu fui eficiente em sentido estrito. Eu consegui reduzir, eu não gastei quinhentos mil, eu gastei trezentos e cinqüenta para poder executar o programa. Estava orçado quinhentos e eu gastei trezentos e cinqüenta, fui econômico. Resta saber qual é o resultado social daquela ação de governo. Porque, às vezes, o que se vai gastar para realizar aquele programa do governo, o mesmo valor aplicado numa outra área da educação poderia resultar em benefícios sociais muito mais significativos para a administração pública, para a sociedade em geral. É o mesmo que se dá no âmbito do asfaltamento de estradas. Eu vou fazer o asfaltamento de estradas. A malha que eu vou asfaltar? Quinhentos quilômetros. Quanto eu vou gastar? Quinhentos mil reais. O que eu vou usar? O próprio DER Departamento de Estradas e Rodagens. Ótimo, consegui fazer os quinhentos quilômetros. Fui eficaz. Gastei menos. Fui econômico. Usei a própria estrutura. Fui eficiente. Resta saber o que aqueles quinhentos quilômetros asfaltados ajudaram em aumento de produção, escoamento da produção do Estado. Passavam vinte carros por ano naquela estrada. Agora, qual o benefício social da ação de governo? Nenhum, ou seja, eu não fui efetivo. Era muito melhor ter direcionado esse recurso para uma outra área em que a escassez de pavimentação asfáltica impossibilita o escoamento de produção. Lá, passa por dia um número significativo de carros muito maior do que na outra estrada. Então, eu vou comparando a efetividade da ação de governo, ou seja, o benefício social. O reflexo para a sociedade e não para um público específico da ação governamental. Esse é o conceito de efetividade.

Bom, dentro dessa noção de eficiência, então, ampliada, é que eu acho que deve ser verificado o âmbito da prestação de serviços públicos no Brasil. Porque a Constituição nos dá o manancial para tanto. E mais, diz que o Tribunal de Contas pode realizar auditorias de gestão. auditorias operacionais para verificar a ocorrência 
desses atos. Veja bem. é necessário ter uma visão ampliada do controle. Não é o controle que vai detectar faltas e aplicar a sanção àquele que não conseguiu atingir metas, não é isso. É tentar acordar, é tentar negociar, consensualizar o atingimento dessas metas na busca de melhores resultados para a própria sociedade. Bom, como poderá acontecer, então, no âmbito das concessões de serviços públicos esse controle de eficiência em sentido amplo por intermédio dos Tribunais de Contas? Lembro a vocês que no que se refere, por exemplo, à política tarifária, que quem opina sobre isso são as agências reguladoras. A normatização do setor não é o Tribunal de Contas quem faz, é a agência reguladora. O que o Tribunal de Contas poderá fazer é fiscalizar a execução do contrato, fiscalização essa voltada para a atuação do poder concedente e não sobre propriamente o concessionário. O Tribunal de Contas fiscaliza a administração direta e indireta. O particular que está a executar o contrato tem deveres contratuais, que uma vez descumpridos, poderá ensejar providências contra ele tomadas pela própria administração. E o Tribunal de Contas o que fará? Voltará o seu controle para a administração justamente para exigir que essas medidas de correção dos rumos na prestação do serviço sejam adotadas, fixando, inclusive, prazos para tanto. Por isso que a Constituição foi sábia e diz que o Tribunal de Contas fixa prazo para o exato cumprimento da lei. E podemos ler essa passagem "fixa prazo para o exato cumprimento Do direito". Aí a eficiência terá lugar, muito mais do que legalidade. E note-se que a lei de concessões nos dá um leque de oportunidades para que isso aconteça. Diz aqui "toda a concessão ou permissão pressupõe a prestação de serviço adequado" - serviço adequado - "ao pleno atendimento dos usuários", ou seja, efetividade. O atendimento é do usuário." conforme estabelecido em lei nas normas pertinentes e nos contratos". Ótimo. Parágrafo primeiro: "Serviço adequado é o que satisfaz as condições de regularidade, continuidade, eficiência e sentido estrito, segurança, atualidade, generalidade, cortesia, prestação e modicidade das tarifas". Eficiência em sentido amplo. Parágrafo segundo: "A atualidade compreende modernização de técnicas e equipamentos e instalações e a sua conservação, bem como a melhoria e a expansão dos serviços". Eficiência. Direitos e obrigações dos usuários, artigo $7^{\circ}$ : "Sem prejuízo do disposto na Lei 8.078, o Código de Defesa do Consumidor, são direitos e obrigações dos usuários: inciso I - receber serviço adequado" Serviço adequado está definido na lei. Serviço eficiente. Do contrato de concessão - Artigo 23: "São cláusulas essenciais do contrato de concessão: modo, forma e condições de prestação de serviço; critérios, indicadores, fórmulas e parâmetros definidores da qualidade do serviço; forma de fiscalização das instalações dos equipamentos, dos métodos e das práticas de execução dos serviços, bem como a indicação dos órgãos competentes para exercê-los". Está aqui. Quem é que vai ser o objeto de fiscalização por parte dos Tribunais no caso da execução de serviço? Os órgãos ou entidades competentes para exercer a fiscalização da execução do contrato de concessão. Desse modo é possível realizar o controle. São encargos do poder concedente, por exemplo, aplicar as penalidades regulamentares e contratuais. Cumprir e fazer cumprir as posições regulamentares do serviço e as cláusulas contratuais da concessão. O poder concedente tem essa incumbência, zelar pela boa qualidade do serviço, receber, apurar e solucionar queixas e reclamações dos usuários que serão certificados em até trinta dias das 
providências tomadas. Isso é encargo do poder concedente de modo que, no meu entender, é possível fiscalizar, até mesmo para sugerir o Tribunal de Contas numa apuração desta ordem a intervenção do poder concedente no âmbito da concessão. Por isso que o artigo 32 diz: "o poder concedente poderá intervir na concessão com o fim de assegurar a adequação na prestação do serviço, bem como o cumprimento fiel das normas contratuais, regulamentares e legais pertinentes". Daí que o manancial para que os Tribunais de Contas possam fiscalizar o âmbito das concessões é total, desde que o façam não de uma maneira repressiva, esquecendo, por exemplo, que a concessão envolve um serviço público, um serviço que é voltado para a sociedade, e que, ainda, que haja uma irregularidade, é muito melhor, às vezes. suportá-la durante um período dado, possibilitando que o órgão ou entidade corrija os rumos do que, simplesmente, adotar providências para sustar o contrato de concessão, causando muito mais malefício à sociedade.

Ressalta-se dessa maneira a importância, então, de um juízo de controle prospectivo, de um juízo de propulsão, de uma idéia de controle correção, ao invés de uma idéia de controle repressão, de controle penalidade, de controle sanção. Sobretudo nessa seara de serviços públicos concedidos.

Para ilustrar a minha exposição eu trago à tona um julgado do Tribunal de Contas da União, sobre a rede ferroviária federal, por intermédio de uma provocação da Câmara Municipal de Juiz de Fora em Minas Gerais, que diz, que, na exploração da concessão de bens públicos, no caso do serviço público que era a rede ferroviária, estava havendo desperdício, estava havendo um não-atingimento de metas, estava havendo uma série de coisas e o Tribunal de Contas da União fez um levantamento em cima dessa concessão. Realmente apurou as irregularidades e ao invés de, obviamente, aplicar sansões, deram provimento parcial a essa representação que foi realizada. Ou seja, realizaram auditoria de gestão, deram provimento parcial determinando recomendações para que o órgão ou entidade providenciasse a melhoria da prestação do serviço e, claro, atingisse aquelas metas que estavam estabelecidas em contrato, por intermédio daquelas concessões que haviam sido realizadas pela rede ferroviária federal. E olha que ela já estava em liquidação extrajudicial. Quer dizer, eles fizeram, inclusive, mandando intimar o interventor da rede para que prestasse esclarecimento sobre a adoção dos procedimentos contra os concessionários. Ou seja, adotando recomendaçōes e fixando prazo para a comprovação de que aquelas recomendações haviam sido adotadas. Ou seja, nitidamente, um controle que busca correção de rumos, que busca detecção de faltas e propositura de soluções, do que um poder que é voltado exclusivamente à sana]o. Porque hoje, é necessário vislumbrar a atividade de controle não como um controle de repressão. Mesmo no âmbito do Ministério Público, por exemplo, que tem sido muitas vezes um algoz dos administradores públicos, hoje há uma tendência para a utilização dos chamados termos de ajustamento de conduta, que se voltam para correção de rumos, dando um crédito de boa fé ao administrador público. $\mathrm{E}$ os Tribunais de Contas também podem fazê-lo. Eu, na minha tese de doutoramento, defendo que como resultado das auditorias de gestão, os Tribunais de Contas deveriam criar um termo de ajustamento de conduta. A base normativa para isso, é o artigo 71. IX, da Constituição quando diz que o Tribunal de Contas assina prazo para o exato cumprimento da lei, do Direito, 
bem como a lei de responsabilidade fiscal, quando trata do alerta no parágrafo $1^{\circ}$, do artigo 59, sobretudo, o inciso V. Então base legal para um termo de ajustamento de conduta no âmbito dos Tribunais de Contas existe. O Tribunal de Contas detectaria a falta, chamaria o responsável, contrataria com ele, a melhora do desempenho, ou seja, faria um termo de ajustamento, um contrato, portanto, para que ele, em dado período a ser fixado neste termo, adotasse as medidas para o exato cumprimento da lei. Eu até batizei esse termo. Chama-se TACTC - Termo de Ajustamento de Conduta do Tribunal de Contas. Para que ajustamento? Para chamar o administrado para perto, afinal, controlar é uma atividade, como eu disse, que pressupõe não só detectar as faltas, mas também propor soluções. $\mathrm{E}$ isso dá muito mais resultado, e mais, diminui o fosso que há entre os Tribunais de Contas e os fiscalizados.

Esse é um grande defeito dessa instituição. Aliás, da administração pública em geral. É necessário diminuir esse espaço. Então, para poder pegar aquele que, efetivamente, vilipendia o patrimônio público, é mais fácil estar perto dele do que estar longe. E fazer um controle que separa o joio do trigo. O princípio é o princípio da boa fé, e não o contrário. Com essas palavras eu espero ter esclarecido alguma coisa. Agradeço a atenção de todos. Muito obrigado. 